\section{Metrical Analysis of a Putative Source for Semi-seedlessness in Rabbiteye Blueberry, Vaccinium ashei Reade.}

\author{
M.K. Ehlenfeldt ${ }^{1}$ \\ U.S. Department of Agriculture, Agricultural Research Service, Rutgers \\ Blueberry and Cranberry Research Center, Chatsworth, NJ 08019
}

\section{M.R. Hall ${ }^{2}$}

Department of Horticulture, University of Georgia, Coastal Plains Experiment Station, Tifton, GA 31793

Additional index words. parthenocarpy, ovule

\begin{abstract}
T 286, a rabbiteye blueberry selection from a 'Delite' $\mathrm{x}$ 'Tifblue' cross, generally has been regarded as producing semi-seedless fruit. A comparison of nonpollinated flowers of T 286, 'Delite', and 'Tifblue' showed no differences in ovule count, and comparisons of ovules at 10, 20, and 40 days from manual cross-pollination showed no obvious evidence of embryo abortion. Manually cross-pollinated flowers contained 85, 60, and 38 seeds per fruit for 'Delite', 'Tifblue', and T 286, respectively. Open-pollinated fruit of $\mathbf{T} 286$ had a seed count similar to that of open-pollinated 'Tifblue' but possessed significantly heavier fruit. The number of seed in $\mathrm{T} \mathbf{2 8 6}$ and 'Tifblue' indicates a tendency toward parthenocarpy.
\end{abstract}

Seedlessness is a valuable trait that greatly enhances fruit quality and marketability of some types of small fruit. The best example of this enhancement is the grape, Vitis vinifera L., in which a form of seedlessness, termed stenospermocarpy, results in the true absence of seed (Pratt, 1971). Most grapes marketed today for table consumption are seedless. In grape, absence of seed is a multiallelic trait controlled by two dominant genes and several modifiers (Stout, 1936, 1939). Seedless $\times$ seedless clone crosses require using embryo rescue to recover seedlings; however, seeded $\times$ seedless-type crosses segregate seedless phenotypes at variable frequencies, depending on the genotype of the female parent.

Rabbiteye blueberries generally are considered to have several fruit characteristics that are less desirable than those of highbush blueberries (Vaccinium corymbosum L.). These characteristics include blander flavor, tougher skins, and greater seediness. In their favor, they possess excellent firmness, a small pedicel scar, and excellent adaption for the soil and climate conditions in the southern United States where they are generally grown.

Several selections of $V$. ashei have low seed counts (personal observation), and although there is minor documentation regarding this characteristic (Austin and Bondari, 1993; Kushima and Austin, 1979), its causes are unknown. While this character is of inter-

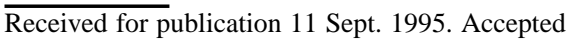
for publication 4 Dec. 1995. The cost of publishing this paper was defrayed in part by the payment of page charges. Under postal regulations, this paper therefore must be hereby marked advertisement solely to indicate this fact.

${ }^{1}$ Research Geneticist.

${ }^{2}$ Associate Professor.

in relation to improved fruit quality, it al is of interest because fruit development with low seed counts may imply a reduced need for cross-pollination. Rabbiteye blueberries generally are considered marginally self-fertile and are substantially less self-fruitful than highbush blueberries (El-Agamy et al., 1981; Garvey and Lyrene, 1987; Meader and Darrow, 1944).

Positive correlations have been documented between seed count and fruit size in $V$. corymbosum (Brewer and Dobson, 1969; Darrow, 1941, 1958; Eaton, 1967; Meader and Darrow, 1947; Moore et al., 1972; White and Clark, 1939), V. ashei (Kushima and Austin,

Table 1. Ovule counts in nonpollinated flowers of 'Delite', 'Tifblue', and T 286.

\begin{tabular}{lccc}
\hline Selection & Mean $^{2}$ & Range & SE \\
\hline Delite & 81.7 & $60-98$ & 2.3 \\
Tifblue & 75.7 & $65-85$ & 1.2 \\
T 286 & 74.8 & $57-98$ & 2.2 \\
LSD $_{0.05}$ & 5.6 & & \\
\hline
\end{tabular}

${ }^{\mathrm{z}}$ Mean represents a sample of 20 flowers.

${ }^{2} \mathrm{OP}=$ open-pollinated.

${ }^{\mathrm{y}}$ na $=$ not applicable.
1979; Moore et al., 1972; Tamada et al., 1977), and $V$. angustifolium Ait. (Aalders and Hall, 1961; Jackson et al., 1972; Rabaey and Luby, 1988), based on measurements within and between cultivars. In highbush blueberry, Eaton (1967) found an overall correlation of 0.59 between fruit size and seed count across 13 selections. Moore et al. (1972) found a correlation of 0.64 across 13 highbush cultivars and a correlation of 0.80 across five rabbiteye cultivars. Kushima and Austin(1979) reported a correlation of 0.59 between total seed count and average fruit weight in rabbiteye blueberries, but, notably, found the correlation was nonsignificant $(0.33)$ in fruit heavier than $2.3 \mathrm{~g}$. A lack of correlation between seed count and fruit weight may indicate a tendency toward parthenocarpy. 'Collins', a highbush cultivar, exhibited such a tendency in the study by Moore et al. (1972).

T 286 is a $V$. ashei hybrid that has large fruit and few seed. Field and greenhouse observations showed that seed counts in the field can be low and that fruit may set in the greenhouse without pollination (M.E. Austin, personal communication). Our objective was to evaluate T 286 as a source of semi-seedlessness in V. ashei. We examined the cytological basis of this trait and studied the development and morphology of fruit produced on this clone under field conditions.

\section{Materials and Methods}

Three rabbiteye genotypes were examined: 'Delite', a late midseason variety; 'Tifblue', a widely grown midseason variety; and T 286 , a hybrid of 'Tifblue' and 'Delite', which is an advanced selection from the cooperative breeding program between U.S. Dept. of Agriculture, Agricultural Research Service, and the Univ. of Georgia. Samples and data were collected from plants grown in a selection block in Alapaha, Ga. Statistical analysis of data was made using MSTAT-C (Michigan State Univ., East Lansing).

Field evaluations of fruit development and fertility under cross-pollination were performed by hand-pollinating selected branches and then covering them with cheesecloth to prevent further pollination. 'Delite' and 'Tifblue' were crossed reciprocally, and T 286 was crossed with 'Brightwell', a half-sib from the cross 'Tifblue' $x$ 'Menditoo'. The remain-

Table 2. Fruit weights and seed counts in crosses of 'Delite', 'Tifblue', and T 286.

\begin{tabular}{|c|c|c|c|c|c|}
\hline \multirow[b]{2}{*}{ Cross } & \multirow[b]{2}{*}{$\begin{array}{c}\text { Pollinations } \\
\text { (no.) }\end{array}$} & \multicolumn{2}{|c|}{ Fruit } & \multirow{2}{*}{$\begin{array}{c}\text { Mean fruit } \\
\text { wt } \\
\text { (g) }\end{array}$} & \multirow{2}{*}{$\begin{array}{c}\text { Mean seed/ } \\
\text { fruit } \\
\text { (no.) }\end{array}$} \\
\hline & & $\begin{array}{l}\text { Count } \\
\text { (no.) }\end{array}$ & $\begin{array}{l}\text { Set } \\
(\%)\end{array}$ & & \\
\hline$\overline{\text { Delite, selfed }}$ & 102 & 1 & 1.0 & 1.1 & 71 \\
\hline Delite $x$ Tifblue & 109 & 43 & 39.4 & 1.9 & 85 \\
\hline Delite $\mathrm{OP}^{\mathrm{z}}$ & $\mathrm{na}^{\mathrm{y}}$ & $200^{x}$ & na & 2.0 & 69 \\
\hline Tifblue, selfed & 122 & 2 & 1.6 & 0.9 & 38 \\
\hline Tifblue $x$ Delite & 187 & 82 & 43.9 & 1.8 & 60 \\
\hline Tifblue OP & na & 200 & na & 1.6 & 29 \\
\hline T 286, selfed & 178 & 1 & 0.5 & 0.5 & 0 \\
\hline T $286 \times$ Brightwell & 136 & 55 & 40.4 & 2.0 & 38 \\
\hline T $286 \mathrm{OP}$ & na & 200 & na & 2.2 & 30 \\
\hline
\end{tabular}

xTwo hundred fruit were randomly selected from the open-pollinated fruit available on plants. 
ing flowers on the plant were open-pollinated. To evaluate the potential for self-pollination as a stimulant to fruit development in T 286 compared to its two parents, self-pollinations were handled similarly to cross-pollinations. Fruit from all pollinations were harvested at maturity, and individual fruit weights were recorded. Fruit then were frozen at $-20 \mathrm{C}$ for later evaluation of fruit diameter and seed count. Two hundred open-pollinated berries also were collected from each selection and evaluated for fruit weight and seed count.

For cytological examinations, nonpollinated flowers of the three selections were collected at anthesis. Samples were fixed for $48 \mathrm{~h}$ in a 3 ethanol : 1 acetic acid solution and then transferred to $70 \%$ ethanol. Nonpollinated flowers were evaluated for ovule count and general ovule development. Ovules were counted for 20 flowers from each cultivar. Ovules were cleared using the techniques of Stelly et al. (1984), and ovule development was evaluated by measuring ovule size and observing megagametophyte development. Fruit from open-pollinations were similarly collected at 10, 20, and 40 days postpollination, and developing ovules were evaluated. Fruit development from all postpollination stages was evaluated by measuring diameters of 20 fruit.

\section{Results and Discussion}

Ovule counts differed significantly between 'Delite' and T 286 but not between T 286 and 'Tifblue' (Table 1). Cytological observations of nonpollinated ovules in all three selections corresponded to published reports of normal ovule development (Gough and Shutak, 1978; Stevens, 1919), and no irregularities suggestive of abnormal development were noted in $\mathrm{T}$ 286. Measuring ovule sizes and comparing size-frequency distributions at 10,20, and 40 days postpollination produced no clear indication that the distribution of ovule sizes in T 286 was any different than that of 'Delite' or 'Tifblue' or that any portion of the ovules in T 286 would fail to develop (data not shown). The most noticeable feature of fruit examined at early developmental stages was the larger size of T 286 fruit.

Self-pollinations of the three selections resulted in almost no fruit set (Table 2). This result suggests that, despite anecdotal reports of fruit development without pollination in $\mathrm{T}$ 286 , this is not the case in field-grown plants. Self-pollination also has been reported for T 286 under field conditions (M.E. Austin, personal communication). In our study, fruit production without pollination in the greenhouse is highly variable in T 286 , occurring in some years but not in others. We have noted similar behavior in several $V$. corymbosum clones. The ability of T 286 to set exclusively selfpollinated fruit under natural conditions could not be verified but seems unlikely. Crosspollination produced seed counts similar to ovule counts for 'Delite' and 'Tifblue', but it resulted in relatively lower seed set in T 286 . Because 'Brightwell' is a half-sib of T 286, this reduction may be due to either inbreeding
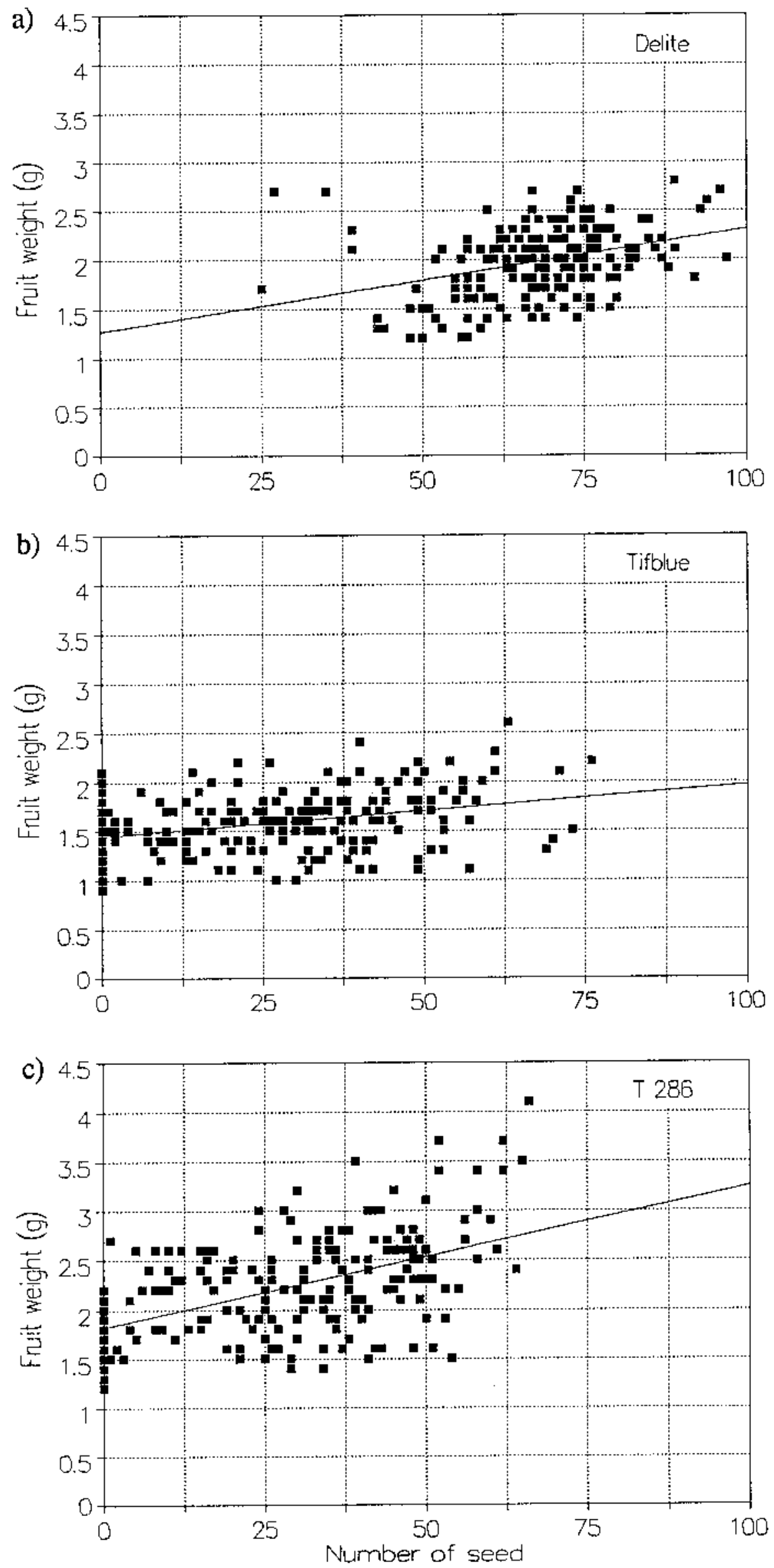

Fig. 1. Fruit weight vs. number of seed per fruit for 200 open-pollinated fruit of (a) 'Delite', (b) 'Tifblue', and (c) T 286 
effects or an innate mechanism of ovule abortion independent of the specific crossing partner.

Examining open-pollinated fruit substantiated the belief that $\mathrm{T} 286$ is a semi-seedless clone but suggests a pollination-based explanation. Comparing average seed counts from 'Delite', 'Tifblue', and T 286 (Table 2) showed that, while the average seed count per fruit (s/ f) for 'Delite' was 69, the averages for 'Tifblue' and T 286 (29 and $30 \mathrm{~s} / \mathrm{f}$, respectively) were not significantly different $\left(\mathrm{LSD}_{0.05}=3\right)$. The regressions of fruit weight on seed count (Fig. $1 \mathrm{a}-\mathrm{c})$ were significant for all three clones $(P<$ $0.001)$. Regression coefficients of 'Delite' and T 286 were not significantly different $(P=$ $0.165)$, but both were different from that of 'Tifblue' $(P<0.020)$. 'Delite' exhibited a tight cluster of data points for seed count and fruit weight (Fig. 1a). Counts generally ranged from 50 to $80 \mathrm{~s} / \mathrm{f}($ mean $=68.5, \mathrm{SD}=11.9)$, and fruit weight generally ranged from 1.1 to $2.5 \mathrm{~g}$ (mean $=2.0)$. 'Delite' showed a moderate increase in fruit weight with increasing seed count (regression equation coefficient $=0.010$ $\mathrm{g} / \mathrm{seed}$ ) and, as might be expected, had a moderately low coefficient of determination $\left(r^{2}=\right.$ 0.127 ). 'Delite' had no fruit with $<25$ seeds and only five fruit $(2.5 \%)$ with $<40$ seed. 'Tifblue' and T 286 (Fig. 1 b and c) generally had from 0 to $60 \mathrm{~s} / \mathrm{f}$, but 'Tifblue' fruit weights generally ranged from 1.0 to $2.0 \mathrm{~g}$ (mean $=1.6$ $\mathrm{g}$ ), while $\mathrm{T} 286$ fruit weights typically ranged from 1.5 to $3.0 \mathrm{~g}$ (mean $=2.2 \mathrm{~g}$ ). The low regression coefficient $(0.005 \mathrm{~g} / \mathrm{seed})$ and low coefficient of determination $\left(r^{2}=0.097\right)$ of the 'Tifblue' plot show that it only had a moderate response of fruit weight to seed count (i.e., a parthenocarpic tendency). The broad distribution for 'Tifblue' resulted in a SD of $18.4 \mathrm{~s} / \mathrm{f}$. T 286 had a response of fruit weight to seed count similar to that of 'Delite' (regression equation coefficient $=0.014 \mathrm{~g} / \mathrm{seed}, r^{2}=0.240$ ), but like 'Tifblue', it can mature normal-sized fruit with few seeds. T 286 had seed counts similar to 'Tifblue', and like 'Tifblue', T 286 had a large sD for seed count (17.5 s/f). Comparisons of the $y$-intercepts of 'Tifblue' and $\mathrm{T}$ 286 regression lines, which may be considered representative weights for essentially parthenocarpic fruit, showed values of 1.4 and $1.8 \mathrm{~g}$, respectively.

Despite earlier indications, T 286 is no less seedy than its parent 'Tifblue', which has never been noted as having few seed, although it has fewer than many other rabbiteye cultivars. The major distinctions that $\mathrm{T} 286$ possesses are larger fruit than either parent and a tendency, like 'Tifblue', to set an appreciable number of reasonably sized fruit with few or no seeds. Seedless 'Tifblue' fruit are only slightly lighter than the cultivar mean $(1.44 \mathrm{~g}$ vs. $1.59 \mathrm{~g}, 91 \%$ of mean). In T 286 , fruit weight is more responsive to seed count, with seedless fruit weight averaging only $82 \%$ of the mean fruit weight. However, the mean weight of T 286 seedless fruit $(1.8 \mathrm{~g})$ is not only higher than the overall mean for 'Tifblue' $(1.6 \mathrm{~g})$ but is heavier than $72 \%$ of all 'Tifblue' fruit.

Typically, rabbiteye blueberries exhibit low self-fruitfulness (El-Agamy et al., 1981; Meader and Darrow, 1944). This characteristic is of special concern because observations of Vander Kloet and Lyrene (1987) of bumble bees pollinating diploid blueberry species suggested that self-pollination predominates under natural conditions. The parthenocarpic tendency of T 286 and 'Tifblue' may be related to their response to pollination. In a study accompanying their work on pollination by bumble bees, Vander Kloet and Lyrene (1987) found that manual pollinations with mixtures of self- and outcross pollen only slightly reduced fruit set compared to outcrossing but reduced seed per fruit by about two-thirds. A similar situation may occur in T 286 and 'Tifblue', in which self-pollen results in no seed and small amounts of outcross pollen trigger normal fruit development. The previously noted average fruit size of T 286, coupled with low seed count, has caused it to be noted in field trials. Although the nature of this response is not what we expected initially, it represents a valuable characteristic if it can be selected and enhanced in progeny. Criteria for selection are a low correlation of fruit weight with seed count (parthenocarpic tendency), seed count skewed toward low values, and an acceptable lower limit for the fruit weight : seed ratio. Heavy fruit (high y-intercept) would allow a considerable latitude for fruit weight : seed ratio, but for lighter fruit, the threshold ratio would require that selections approach true seedlessness.

\section{Literature Cited}

Aalders, L.E. and I.V. Hall. 1961. Pollen incompatibility and fruit set in lowbush blueberries. Can. J. Genet. Cytol. 3:300-307.

Austin, M.E. and K. Bondari. 1993. Fruit quality characteristics of five rabbiteye blueberry cultivars and clones. Acta Hort. 345:133-140.

Brewer, J.W. and R.C. Dobson. 1969. Seed count and berry size in relation to pollinator level and harvest date for the highbush blueberry, Vaccinium corymbosum. J. Econ. Entomol. 62:1353-1356.
Darrow, G.M. 1941. Seed size in blueberry and related species. Proc. Amer. Soc. Hort. Sci. 38:438-440.

Darrow, G.M. 1958. Seed number in blueberry fruit. Proc. Amer. Soc. Hort. Sci. 72:212-215.

Eaton, G.W. 1967. The relationship between seed number and berry weight in open pollinated highbush blueberries. HortScience 2:14-15.

El-Agamy, S.Z.A.,W.B. Sherman, and P.M.Lyrene. 1981. Fruit set and seed number from self- and cross-pollinated highbush $(4 \mathrm{x})$ and rabbiteye (6x) blueberries. J. Amer. Soc. Hort. Sci. 106:443-445.

Garvey, E.J. and P.M. Lyrene. 1987. Self-incompatibility in 19 native blueberry selections. J. Amer. Soc. Hort. Sci. 112:856-858.

Gough, R.E. and V.G. Shutak. 1978. Anatomy and morphology of cultivated highbush blueberry. Rhode Island Agr. Expt. Sta. Bul. 423.

Jackson, L.P., L.E. Aalders, and I.V. Hall. 1972. Berry size and seed number in commercial lowbush blueberry fields of Nova Scotia. Naturaliste Can. 99:615-619.

Kushima, T. and M.E. Austin. 1979. Seed number and size in rabbiteye blueberry fruit. HortScience 14:721-723.

Meader, E.M. and G.M. Darrow. 1944. Pollination of the rabbiteye blueberry and related species. Proc. Amer. Soc. Hort. Sci. 45:267-274.

Meader, E.M. and G.M. Darrow. 1947. Highbush blueberry pollination experiments. Proc. Amer. Soc. Hort. Sci. 49:196-204.

Moore, J.N., B.D. Reynolds, and G.R. Brown. 1972. Effects of seed number, size, and development on fruit size of cultivated blueberries. HortScience 7:268-269.

Pratt, C. 1971. Reproductive anatomy in cultivated grapes-A review. Amer. J. Enol. Viticult. 22:92-109.

Rabaey, A. and J. Luby. 1988. Fruit set in half-high blueberry genotypes following self and cross pollination. Fruit Var. J. 42:126-129.

Stelly, D.M., S.J. Peloquin, R.G. Palmer, and C.F. Crane. 1984. Mayer's hemalum-Methyl salicylate: A stain-clearing technique for observations within whole ovules. Stain Technol. 59:155-161.

Stevens, N.E. 1919. The development of the endosperm in Vaccinium corymbosum. Bul. Torrey Bot. Club 24:465-468.

Stout, A.B. 1936. Breeding for hardy seedless grapes. Proc. Amer. Soc. Hort. Sci. 34:416-420.

Stout, A.B. 1939. Progress in breeding for seedless grapes. Proc. Amer. Soc. Hort. Sci. 37:627-629.

Tamada, T., H. Iwagaki, and S. Ishiawa. 1977. The pollination of rabbiteye blueberries in Tokyo. Acta Hort. 61:335-341.

Vander Kloet, S.P. and P.M. Lyrene. 1987. Selfincompatibility in diploid, tetraploid, and hexaploid Vaccinium corymbosum. Can. J. Bot. 65:660-665.

White, E. and J.H. Clark. 1939. Some results of selfpollination of the highbush blueberry at Whitesbog, New Jersey. Proc. Amer. Soc. Hort. Sci. 36:305-309. 